\begin{tabular}{|c|c|}
\hline (Bisnis dan Man & $\begin{array}{c}\text { Volume 12, Issue 2, April 2020, 140-153 } \\
\text { ISSN 2549-7790 (Online) } \\
\text { ISSN 1979-7192 (Print) } \\
\text { DOI: 10.26740/bisma.v12n2.p140-153 } \\
\text { https://journal.unesa.ac.id/index.php/bisma/index }\end{array}$ \\
\hline
\end{tabular}

\title{
Co-creation strategy in peer-to-peer accommodation in Bandung tourism context
}

\author{
Anna Riana Putriya ${ }^{1 *}$, Utomo Sarjono Putro ${ }^{2}$, Pri Hermawan ${ }^{3}$, and Kyoichi \\ Kijima $^{4}$ \\ ${ }^{\mathbf{1}}$ School of Business and Management, Institut Teknology Bandung, Indonesia \\ Jl. Ganesha 10, Bandung, Jawa Barat, Indonesia \\ anna_riana@sbm-itb.ac.id \\ ${ }^{2}$ School of Business and Management, Institut Teknology Bandung, Indonesia \\ Jl. Jl. Ganesha 10, Bandung, Jawa Barat, Indonesia \\ utomo@sbm-itb.ac.id \\ ${ }^{3}$ School of Business and Management, Institut Teknology Bandung, Indonesia \\ Jl. Jl. Ganesha 10, Bandung, Jawa Barat, Indonesia \\ prihermawan@sbm-itb.ac.id \\ ${ }^{4}$ School of Management, Daito Bunka University, Japan \\ Takashimadaira, Itabashi-ku, Tokyo, Japan \\ kijima@kijima-lab.com
}

\begin{abstract}
Collaborative economy refers to social and economic sharing activities that make entities (customer and peer provider) in-service ecosystem can access services through technology or digital platform. This research aims to give a better understanding of activities and interaction between entities that can potentially elevate the existence of peer-to-peer (P2P) accommodation in Indonesia. Although research regarding the collaborative economy has been accelerating, there has not been a formal conceptualization of interaction from a broadening perspective as a service ecosystem in the context of co-creation. Preliminary study becomes crucial and relevant with the raising of the collaborative economy, based on the consideration that no previous research is considered to be able to explain the dynamics of interaction by using a perspective of Service-Dominant Logic (S-D Logic). This study seeks to answer two research questions, what interactions occur outside consumers, peer providers, platform providers, and how co-creation might be created in the P2P service ecosystem. This conceptual paper draws on the interaction from the perspective of cocreation between entities and stakeholders as a lens by using the systematic-qualitative approach. In general, this study uses the Soft System Methodology (SSM) precisely defining an unstructured situation in the real world. This study tries to initiate the development of phases of co-creation between entities in the service ecosystem. The

\section{How to cite this document:}

Putriya, A.R., Putro, U.S., Hermawan, P., \& Kijima, K. (2020). Co-creation strategy in peer-to-peer accommodation in Bandung tourism context. BISMA (Bisnis dan Manajemen), 12(April), 140-153. https://doi.org/10.26740/bisma.v12n2.p140-153
\end{abstract}


BISMA (Bisnis dan Manajemen)

Volume 12 Issue 2, April 2020

E-ISSN 2549-7790, P-ISSN 1979-7192

Page 140-153

outcomes of this study enrich the body of knowledge of service science, especially on the way to apply the framework value co-creation. The development of a better service ecosystem across particular engagement remains critical.

Keywords: collaborative economy; service-dominant logic; service management; service science.

Received: January 23, 2020; Accepted: February 27, 2020; Published: April 28, 2020

*Corresponding author

Email: anna_riana@sbm-itb.ac.id

\begin{abstract}
Abstrak
Ekonomi kolaboratif mengacu pada aktivitas sosial dan ekonomi yang membuat entitas (pelanggan dan penyedia layanan) dalam ekosistem bisnis dapat mengakses layanan melalui teknologi atau platform digital. Penelitian ini bertujuan untuk memberikan pemahaman yang lebih baik tentang kegiatan dan interaksi antar entitas yang berpotensi meningkatkan keberadaan akomodasi peer-to-peer (P2P) di Indonesia. Meskipun penelitian mengenai ekonomi kolaboratif semakin berkembang, belum ada konseptualisasi formal interaksi dari perspektif yang lebih luas sebagai ekosistem bisnis dalam konteks penciptaan bersama atau co-creation. Studi pendahuluan menjadi penting dan relevan dengan peningkatan ekonomi kolaboratif, berdasarkan pada pertimbangan bahwa tidak ada penelitian sebelumnya yang dianggap dapat menjelaskan dinamika interaksi dengan menggunakan perspektif Service-Dominant Logic (S-D Logic). Studi ini berupaya menjawab dua pertanyaan penelitian, interaksi apa yang terjadi di luar tiga entitas utama (konsumen, penyedia layanan, platform digital) dan bagaimana co-creation dapat dibuat dalam ekosistem bisnis P2P. Penelitian konseptual ini mengacu pada interaksi dari perspektif co-creation antara entitas dan pemangku kepentingan sebagai lensa dengan menggunakan pendekatan sistematis-kualitatif. Secara umum, penelitian ini menggunakan desain penelitian Soft System Methodology (SSM) tepatnya adalah tahap pertama dan kedua yang mendefinisikan situasi tidak terstruktur di dunia nyata. Studi ini mencoba untuk memulai pengembangan fase kreasi bersama antara entitas yang melibatkan pelanggan, penyedia layanan, platform digital, dan entitas lain dalam ekosistem layanan. Hasil dari penelitian ini memperkaya ilmu pengetahuan layanan, terutama tentang cara menerapkan kerangka penciptaan nilai dalam konteks akomodasi peer-to-peer. Pengembangan ekosistem layanan yang lebih baik melalui berbagai interaksi di akomodasi P2P sangat krusial saat ini di era ekonomi kolaboratif.
\end{abstract}

Keywords: ekonomi kolaboratif; service-dominant logic; manajemen layanan; ilmu layanan.

\title{
INTRODUCTION
}

Participants in a collaborative economy consisting of three main entities, customers - peer providers - platform providers, do their activities by sharing access (product or services) and coordinating those experiences in digital platforms. In the context of tourism precisely accommodation sector, collaborative economy companies such as Airbnb do not maintain inventory, and they match owners of properties (hosts or peer providers) with their prospective customers (guests). 
Generally, renting in the digital platform is more affordable than renting from traditional service providers like hotels (Zervas, Proserpio, \& Byers, 2017). This peer-to-peer $(\mathrm{P} 2 \mathrm{P})$ business models offer extra income for peer-service providers, meanwhile also offers convenience to the customers.

A digital platform such as Airbnb facilitates the co-creation process that generated by both customers and peer service providers (dyadic interaction). Cocreation also happens in the interaction between the peer service provider and the service platform. Service-Dominant Logic (SDL) explains the co-creation developed simultaneously by consumer and service provider (Chandler \& Vargo, 2011). SDL is a concept that the customers actively participate and collaborate with the provider in exchanges; customers co-create value with the service provider. Interaction between the entities involved in the collaborative economy is recognized as an essential mid-range concept linking with the Service-Dominant Logic (SDL) perspective (Brodie, Saren, \& Pels, 2011).

Broadening the theoretical viewpoint on "beyond the dyadic" interaction exposes facets of this process that previous research has remained unaddressed. Service ecosystems, as to form of beyond dyadic interaction, giving some "nested" views (Klijn \& Haes, 1994). From the perspective of SDL, the service ecosystem is the fundamental unit of analysis (Vargo et al., 2017) and provides an accurate lens for a deeper understanding of the interaction of the entities as the underlying concept. The SDL describes service ecosystems as a "relatively self-contained, selfadjusting system of resource-integrating entities connected by shared institutional arrangements and mutual value creation through service exchange" (Vargo \& Lusch, 2014).

An ecosystem view highlights that each actor engages with other entities in a multitude of co-existing processes of value creation (Vargo \& Lusch, 2016). While existing research provides valuable insight into the interaction of a range of service entities, it has not yet considered how different contexts of interaction are linked to each other, and importantly, how an entity can coordinate interaction with multiple objects at the same time. So what is lacking is a broader communication viewpoint that takes into account the different contexts in which interaction patterns are rooted. This paper aims to extend the established understanding of actor interaction by analyzing it from multiple levels of aggregation perspective, beyond its typically primarily dyadic emphasis (Vargo \& Lusch, 2017).

An ecosystem view emphasizes that each actor interacts with other entities in a multitude of coexisting processes of value creation (Vargo \& Lusch, 2016). The concept of service-dominant logic, (Vargo \& Lusch, 2004) argues that value is no longer part of tangible offerings, but it has been co-created with customers through meaningful interaction experiences (Prahalad \& Ramaswamy, 2004). The increasing popularity of share economy enterprises can be explained by ServiceDominant Logic (SDL), proposed by Vargo \& Lusch (2004). SDL argues that the paradigm has moved from company-centered value-generation to consumer co- 
creation (Shaw, Bailey, \& Williams, 2011). DL stresses as this allows for value creation, the importance of interaction between consumers and service providers (Vargo \& Lusch, 2008). In a tourism management context, Shaw et al. (2011) introduced the concept of the SDL as a research paradigm and debated SDL's main features in terms of the experiential economy in particular.

\section{SERVICE-DOMINANT LOGIC IN MANAGEMENT CONTEXT}

The concept of service-dominant, (Vargo \& Lusch, 2004) states that value is no longer embedded intangible offers, but that it is co-created by meaningful interactions with services with customers (Prahalad \& Ramaswamy, 2004). In tourism and hospitality research, S-D logic and concept of co-creation experiences are integrated (Tussyadiah \& Zach, 2017), which suggests that this research is relevant for further consideration.

Service in S-D logic means the application of specialized knowledge and skills to another actor or the actor itself (Vargo \& Lusch, 2004). In S-D logic, goods and services are not alternative forms of products. Products are devices that serve as an alternative to the direct service provision (tools, distribution). Service is, therefore, the general and universal case of the exchange procedure, the common denominator, service always exchanged.

There is shifting from the role of the consumer who transforms into a consumer who is capable of a value co-creator (Prahalad \& Ramaswamy, 2000). Engagement that is dynamically created between the entities and the business entities around it enables the creation of value (Galvagno \& Dalli, 2014; Prahalad \& Ramaswamy, 2000). The S-D logic theory states that value created is not something that arises from the relationship of two entities only (dyadic interaction) but also involves many other entities or entities which are, of course, always beneficiary. This beneficiary is a factor that most determines the value within context (Vargo, Wieland, \& Akaka, 2015).

Service-Dominant Logic (SDL) explains the co-creation developed simultaneously by consumer and service provider (Chandler \& Vargo, 2011). SDL is a concept that the customers actively participate and collaborate with the provider in exchanges; customers co-create value with service providers. The value orchestration platform facilitates the co-creation process generated by both customers and service providers. It is assumed that the process involves the four phases of creating value co-creation: co-definition, co-development, co-experience, and co-elevation. Co-definition and co-experience are phased, where the process of attracting customers and providers to get involved in the platform. Meanwhile, codevelopment and co-elevation are the phases of empowerment for customers and service providers (Kijima \& Arai, 2016). These four phases of co-creation phases, as illustrated in Figure 1. 


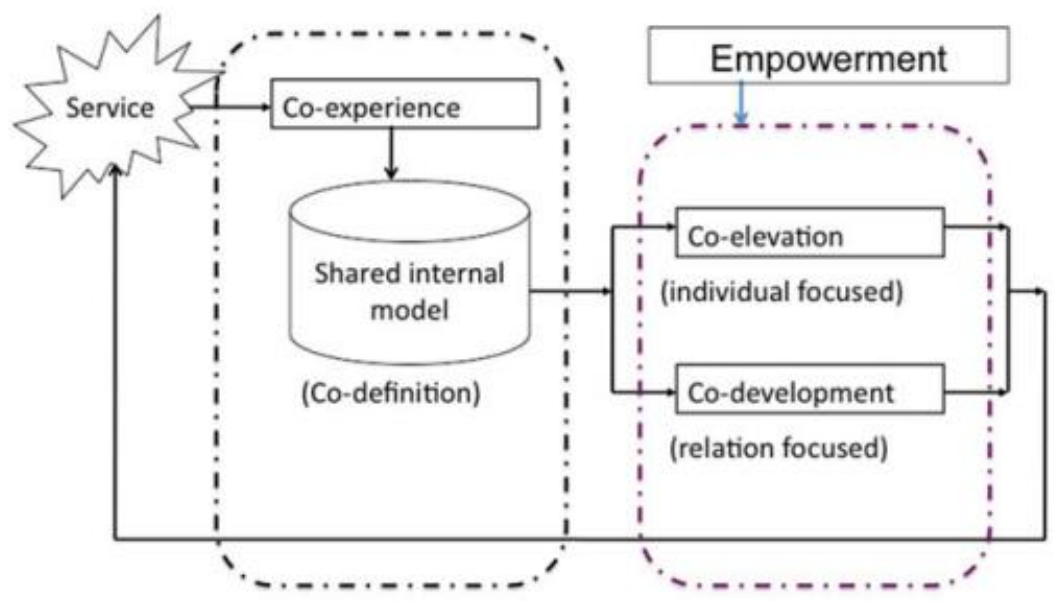

Source: (Kijima \& Arai, 2016)

Figure 1. Models of Value Co-creation

\section{Peer-to-Peer Service Ecosystem}

P2P (peer-to-peer) accommodation used for research is Airbnb, where foreign consumers have a variety of residential alternatives. Unique selling proposition (USP) of Airbnb appears on the tagline "Belong Anywhere" (Ramli, 2015). This is different from its competitors, who simply offer a place to stay at a low price. Airbnb is a platform that tries to capture the potential of each region, along with the uniqueness of different cultural characteristics.

A preliminary study, the online observation, was conducted from April 2018 until October 2018 by observing the interaction between actors (peer service providers and consumers) on Airbnb's website. Observation is done on one peer service provider. Participant observation and in-depth interviews conducted with four peer service providers that have a high rating (super-host). Considering that that is a preliminary study, in the future, it is necessary to conduct a more comprehensive next stage, which focuses on the study on interaction patterns among entities and observes more about the co-creation process that has occurred and the potential co-creation of the process.

\section{METHODS}

This research uses the Soft Systems Methodology as a flexible system approach. Soft Systems Methodology (SSM) is used to structure thinking in a complex problem with qualitative research analysis. In determining the right approach to the research problems that have been formulated, this study use grouping types of system methodology that is arranged based on two dimensions, namely systems and participant (Flood \& Jackson, 1991).

Research that explores peer-to-peer accommodation is in the matrix 'Complex-Pluralist' because of actors (Airbnb as platform provider, peer service provider/host, and customers/guests) involved are pluralists (having essential compatibility of interest, their values and beliefs diverged to some extent, they all 
participate in decision making, and they act following agreed objectives) and complex system (many interactions, a large number of elements, attributes of elements are not predetermined, and the system evolves). The approach used in the complex-pluralist is Soft Systems Methodology or SSM (Flood and Jackson, 1991).

Table 1. Grouping Types of Systm Methodology

\begin{tabular}{lccc}
\hline & System & \multicolumn{3}{c}{ Participant } \\
\hline Simple & Unitary & Pluralist & Coercive \\
\hline \multirow{2}{*}{ Complex } & Simple- & Simple- & Simple- \\
& Unitery & Pluralist & Coercive \\
& Complex- & Complex- & Complex- \\
& Unitery & Pluralist & Coercive \\
\hline
\end{tabular}

Source: Flood \& Jackson (1991)

In SSM, the researcher takes action in a problematical situation in the real world, intervening in it as the first person to improve it, reflects on the experience, and then takes further action based on the reflection (Uchiyama, 2009). SSM aims to gain experience-based knowledge that can be applied to the real world through practice by the researchers themselves, while also attempting to improve the real situation.

Applications of SSM are numerous in the literature. SSM consists of seven stages, starting from identifying unstructured problems to determine systematically desirable and culturally feasible changes, as seen in table 1. There are two parts within SSM, real-world, and systems thinking used for tackling the real world (P Checkland, 2000; Flood \& Jackson, 1991; Mehregan, Hosseinzadeh, \& Kazemi, 2012) as seen in Figure 2.

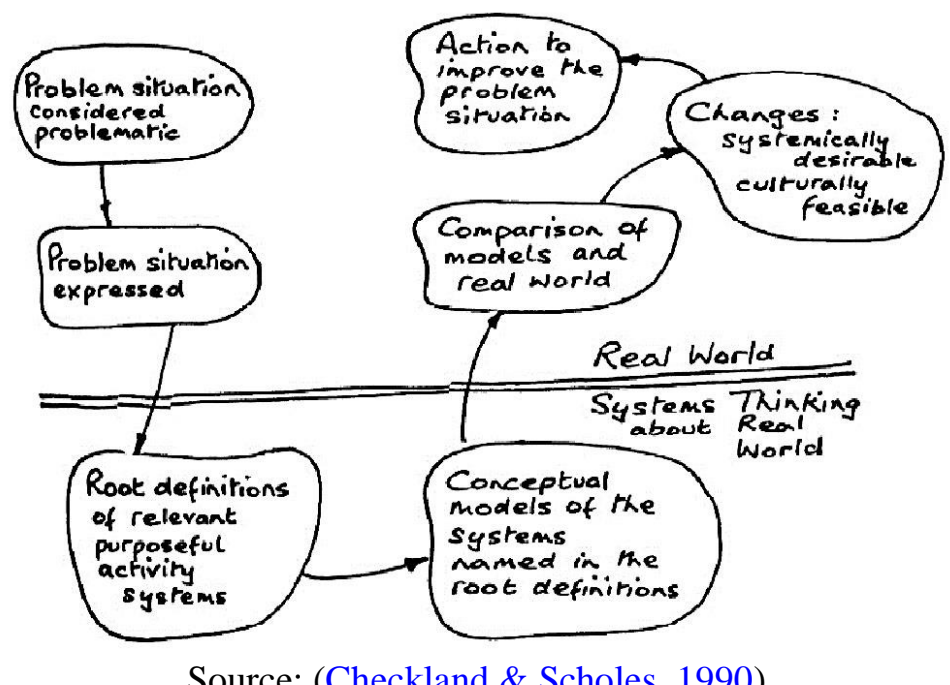

Figure 2. Seven Stage Model of Soft Systems Methodology 
Since SSM consist of two world as illustrated on previous page, the six steps in SSM (Peter Checkland \& Poulter, 2006) are:

Step 1: Identification of unstructured problems.

Collect various kinds of information related to problematic situations.

Result of data collection and interpretation of information will provide an overview of problematic situations in the research context.

Step 2: Problem situation: expressed in rich picture.

Formulates ideas about problematic situations systematically based on the information they obtain.

Step 3: Root definition of relevant systems

Arrange root definition that can describe what, how, and why to enrich questions about the problematic situation

Step 4 : Conceptual model

The models based on root definition guidance, CATWOE analysis, and $3 \mathrm{E}$ (Efficacy, Efficiency, and Effectiveness) criteria.

Step 5: Comparison of 4 (model) and 2 (reality)

Compare the results of their research studies with real-world realities.

The comparative results will be a guide in designing changes

Step 6: Challenges

Analyzes and interprets problematic situations based on the comparison made beforehand.

Step 7 : Action to improve problem situation

Considering that this paper is a preliminary study, what has been done in this stage is online observation. This preliminary study is an initial work using SSM to gain a more in-depth understanding of the problem situation from multiple entities involved in the service system.

The online observation was conducted in 2017-2018 by observing the interaction between entities (peer service provider and consumers) in Airbnb's website also other entities in the service ecosystem. This process was done by analyzing 50 online reviews provided by consumers to three different hosts and vice versa. Participant Observations are done in peer service providers along in 2018 and 2019 with more than 12 participant observations. The unit of analysis in this study are customers (foreign tourists who come to Indonesia), peer providers (the owner of the property that leases the area of his house where he does not live separately and can interact directly with customers). In-depth interviews conducted with five peer service providers that have a high rating (super-host) along in 2018 and 2019. Besides, interviews were also held for consumers who had stayed using Airbnb in Bandung and several other destinations as a comparison and also conducted in-depth interviews with five consumers who also had accommodations that were rented through Airbnb. This is done to analyze the double role in the collaborative economy and their experience in conducting the co-creation process. 
$\mathrm{P} 2 \mathrm{P}$ accommodation used for this research is Airbnb, where consumers have a variety of residential alternatives. Unique selling proposition (USP) of Airbnb appears on the tagline "Find homes on Airbnb." This is different from its competitors, who simply offer a place to stay at a low price. Airbnb is a platform that tries to capture interaction that unleashes the potential of each region, along with the uniqueness of different cultural characteristics.

\section{RESULT AND DISCUSSION}

As the existing literature of Service-Dominant Logic (SDL) and the concept of co-creation have been integrated into tourism sector (Tussyadiah \& Zach, 2017) and its relevance to fill this theoretical gap as it is addressed by previous research that is how to employ different perspective (SDL) and how to transform the interaction between entities of service ecosystem into co-creation (Kijima \&Arai, 2016; Vargo \& Lusch, 2017; Zervas et al., 2017) by using different approach and methodology in the context of peer-to-peer accommodation especially in developing country that heavy in different cultural issues toward the collaborative economy, this study aims to give a better understanding of activities and interaction between entities that potentially can elevate the co-creation process and the existence of peer-to-peer (P2P) accommodation in Indonesia, especially in Bandung as a creative city.

Analysis that resulted from participant observation shown that the service platform brings together two main entities, peer service providers and consumers, the goal of getting as many peer providers as possible is as important as bringing in as many consumers as possible. The process begins with a peer service provider registering his / her home to Airbnb as a service platform, once approved the critical thing that the homeowner must do is contact the community leader to inform informally that his house will be a place to stay from several people including foreign tourists. This stage becomes very important for business sustainability because of the magnitude of potential conflicts that can occur in the future due to cultural differences.

Result of observation and interview session shows that service system used to enhance the entities in the service process. The perspective of service system used to represent where value creation occurs between the entities and recognizes the part of value creation can occur in the long term after peer service providers have generated their contribution to consumer value. Based on Figure 3, representing the engagement of entities in-service system that wrapped on the interaction among entities by examining the entities from the customer, peer provider, platform provider, and other customer appears that many entities have interaction into another party that can be identified from a house owned by peer-provider, neighborhood association or leader, local community, concerned neighbors, to the 
culinary sector, bank, social media network, and local facility center and public transportation (Putriya, Hermawan, Novani, \& Putro, 2018).

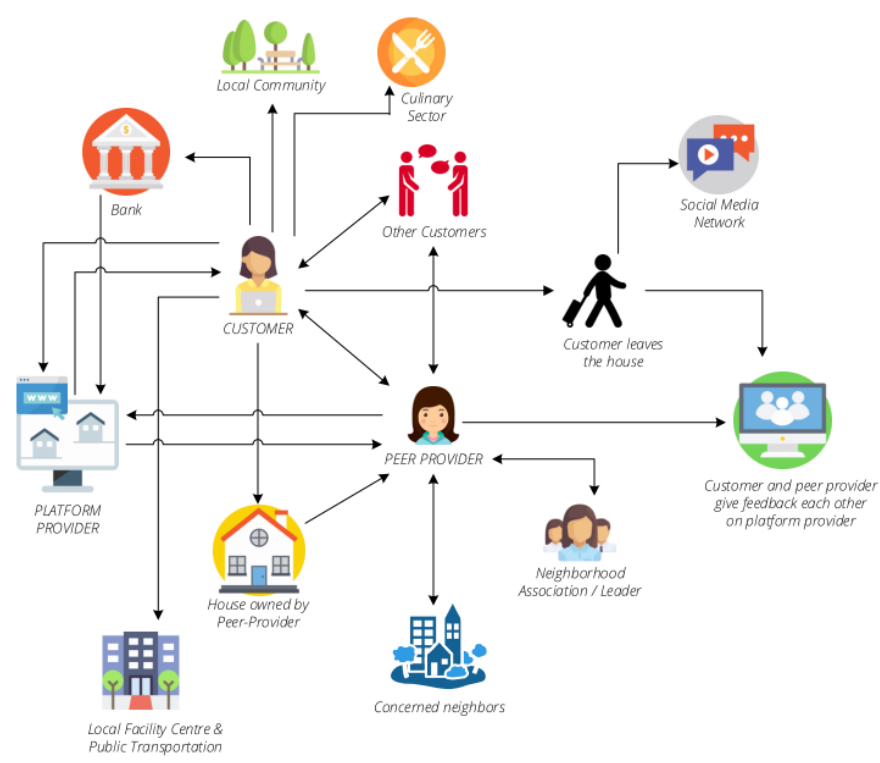

Source: (Putiya et al., 2018)

Figure 3. Service System - Interanction among Entities

The approach to value co-creation places the meaning source within the cocreation process, which is actualized in co-creative experiences by entities. It is built deliberately by strategically aligned players, processes, and interfaces to cocreate value propositions and outcomes (Ramaswamy \& Chopra, 2014), while they aim to build effective engagement. In essence, it was concluded that co-creation is the mutual creation of value and experiences between entities in a service ecosystem (Novani, Putro, \& Hermawan, 2014).

Engagement platforms (Airbnb) also enable new experiences to be provided by ensuring that entities have the opportunity to co-create their unique results (services and experiences) as seen in table 1 (Putiva et al., 2018). Co-creative interaction framework as enlightening the engagement stakeholders in service ecosystem to enhance value co-creation that was focusing on creating value within multiple stakeholders and user experience, social resource, and interaction also focus on the power of service system.

The framework for interaction co-creation is developed by considering the critical point of integrating service entities, processes, and interfaces aiming to cocreate the value propositions and results (Putiva et al., 2018). Based on figure 2, the next step is to examine the process of co-creation of values between entities generated in this interaction.

Model of value co-creation in figure 1 focus on not only platforms as service regulator but also service ecosystems in accommodation of collaborative economy. The concept of a platform, on the one hand, refers to the first part, where different actors meet each other and become interested in co-creating value. On the other 
hand, the concept of ecosystems refers to the second part, where co-creation of the actual value takes place in four significant phases of interaction (Kijima \& Arai, 2016). Value co-creation phases associated with the co-creation process that occurs with diagram 2 then it can be identified that:

Phase 1: Co-experience. Occurs in the interaction between customer - peer provider - provider platform and other entities, i.e. 'other customers.'

Phase 2: Co-definition. This occurs in the same interaction pattern with phase 1, but in phase 2, this is something called 'shared internal model' to define collectively about customer needs and preferences and provider's direction.

Phase 3: Co-elevation. Currently, Airbnb seeks to increase the quality of interaction between peer provider with the customer that is for increased interaction quality is given rewards to the peer provider in the form of vouchers that can be used when he will stay at home peer, other providers, if he has a rating or assessment of at least 80 percent or socalled with an annual travel credit program of $\$ 100$. Based on the level of competition is high enough with other provider platforms, then Airbnb needs to do co-elevation. The driving force of this co-elevation is the competitiveness among service platforms. It aims to increase the standard of interaction provided by peer providers to create new standards of hospitality services. Efforts to create phase 3 can be made superhost award program consisting of two sub-programs, namely the award to the service to new customers and loyal customers who successfully performed by peer provider. The reward is given not only in the form of travel credit but also in cash, so it is very measured and liquid.

Phase 4: Co-development. Once phase 3 is created, it is expected to be aligned with phase 4 , where there is co-development between the three parties, not only between peer providers and consumers but also with service platforms. If we look again at diagram 4 on the previous page, then the next co-development is expected to be able to have implications on more entities, especially local communities and concerned neighbors so that the sustainability of this business ecosystem provides benefits to more entities or in a broader scale capable of creating co-creation process as its output.

The co-creation model explicitly defines service as a value co-creation interaction between customers and service providers and identifies four phases that occur in the process. The first two phases, co-experience, and co-definition are relatively short-range concepts for describing service appreciation, while the final 
two phases, co-elevation, and co-development refer to the long-range activities necessary for service innovation.

In value co-creation process on this theoretical framework requires more significant efforts, especially for customer and host/peer providers, compare to what is happening in the non-P2P business model. All actors or stakeholders must clearly define their expectations. Peer service providers or hosts are providing cocreation capability. It may, however, be too easy to assume that the preferences, expectations, or capacities of both parties are known when participating in the cocreation process. This consideration leads us to the idea of service as a dynamic process interaction in which customers and service providers learn from one another and work together.

As a research initiation, the framework of ecosystem services in the $\mathrm{P} 2 \mathrm{P}$ context can be used to assist in providing an understanding that the success of the collaborative economy is not only limited to how interactions occur in only three main entities but also involves the interaction between broader entities. The success of the growth of the tourism industry, especially in the accommodation sector in Indonesia, is determined by how to create ecosystem service orchestration given the many barriers and rejection from other entities and the unresolved constraints on the trust issue.

\section{CONCLUSION}

This study provides valuable insight into the coexistence in the studied collaborative economy of various value creation practices, particularly in accommodation. In doing so, both theoretical and empirical understanding is provided regarding the value co-creation practices. For theoretical contribution, the outcomes of this study enrich the body of knowledge of service science, especially on the way to apply the framework of previous research on value co-creation within the context of peer-to-peer accommodation, which in line with the previous model of co-creation (Kijima \& Arai, 2016). For practical implication, the digital platform is a significant venue for actors within the service ecosystem to share their value. Also, this study complements the earlier perspective of how value co-creation (Adner, 2016) can be created in a collaborative economy context. In brief, if each entity acknowledges the impact of various interaction and concurrent engagement frameworks within which an entity is involved, we will work to improve the responsibilities through some support mechanism. Finally, the development of a better service ecosystem across particular engagement contexts also remains critical in body knowledge of service science. In the context of the collaborative economy, the implementation of co-creation is more complicated compare to in conventional business model (Kijima \& Arai, 2016).

This research has several research limitations, including the limited area covered is the city of Bandung. However, each region in Indonesia certainly has different uniqueness so that the level of generalization. Considering that it is a 
preliminary study, in the future, it is necessary to conduct a more comprehensive next stage, which focuses on the study on interaction patterns among entities and observes more about the co-creation process that has occurred and the potential cocreation of the process.

\section{REFERENCES}

Adner, R. (2016). Ecosystem as Structure: An Actionable Construct for Strategy. Journal of Management, 20(10), 39-58. http://doi.org/10.1177/0149206316678451

Brodie, R. J., Saren, M., \& Pels, J. (2011). Theorizing about the service-dominant logic: The bridging role of middle-range theory. Marketing Theory, 11, 7591. http://doi.org/10.1177/1470593110393714

Burge, S. (2015). An Overview of the Soft Systems Methodology. In System Thinking: Approaches and Methodologies (pp. 1-14). Retrieved from http://www.burgehugheswalsh.co.uk/Uploaded/1/Documents/Soft-SystemsMethodology.pdf

Chandler, J. D., \& Vargo, S. L. (2011). Contextualization and value-in-context: How context frames exchange. Marketing Theory, 11, 35-49. http://doi.org/10.1177/1470593110393713

Checkland, P. (2000). Soft Systems Methodology: A Thirty Year Retrospective. Systems Research and Behavioural Science, 17, 11-58. http://doi.org/10.1002/1099-1743(200011)17:1+<::AIDSRES374>3.0.CO;2-O

Checkland, P., \& Scholes, J. (1990). Soft Systems Methodology in Action. John Wiley.

Flood, R. L. ., \& Jackson, M. C. (1991). Creative Problem Solving. John Wiley.

Galvagno, M., \& Dalli, D. (2014). Theory of value co-creation: A systematic literature review. Managing Service Quality, 24, 643-683. http://doi.org/10.1108/MSQ-09-2013-0187

Holwell, S. (2000). Soft Systems Methodology: Other Voices. Systemic Practice and Action Research, 13(6), 773-797. http://doi.org/10.1023/A:1026479529130

Kijima, K., \& Arai, Y. (2016). Value Co-creation Process and Value Orchestration Platform. In Global Perspectives on Service Science: Japan (pp. 137-154). http://doi.org/10.1007/978-1-4939-3594-9

Klijn, F., \& Haes, H. A. U. De. (1994). A hierarchical approach to ecosystems and its implications for ecological land classification. Landscape Ecology, 9, 89- 
104. Retrieved from https://link.springer.com/article/10.1007/BF00124376

Mehregan, M. R., Hosseinzadeh, M., \& Kazemi, A. (2012). An application of Soft System Methodology. Procedia - Social and Behavioral Sciences, 41, 426433. http://doi.org/10.1016/j.sbspro.2012.04.051

Novani, S., Putro, U. S., \& Hermawan, P. (2014). An Application of Soft System Methodology in Batik Industrial Cluster Solo by Using Service System Science Perspective. Procedia - Social and Behavioral Sciences, 115, 324 331. http://doi.org/10.1016/j.sbspro.2014.02.439

Prahalad, C. K., \& Ramaswamy, V. (2000). Co-Opting Customer Competence. Harvard Business Review. http://doi.org/10.1086/250095

Prahalad, C. K., \& Ramaswamy, V. (2004). Co-creation experiences: The next practice in value creation. Journal of Interactive Marketing, 18, 5-14. http://doi.org/10.1002/dir.20015

Putriya, A. R., Hermawan, P., Novani, S., \& Putro, U. S. (2018). Peer-to-Peer Accomodation Service Process: A Framework of Service Blueprint. In Advances in Economics, Business, and Management Research, 72, 211-217. http://doi.org/10.2991/icbmr-18.2019.35

Ramaswamy, V., \& Chopra, N. (2014). Building a culture of co-creation at Mahindra. Strategy and Leadership, 42, 12-18. http://doi.org/10.1108/SL$\underline{01-2014-0005}$

Ramli, D. (2015, July 20). Telstra, Airbnb battle over "Belong” tagline. The Sydney Morning Herald, p. business. Sydney. Retrieved from https://www.smh.com.au/business/telstra-airbnb-battle-over-belong-tagline20150720-gig6d6.html

Shaw, G., Bailey, A., \& Williams, A. (2011). Aspects of service-dominant logic and its implications for tourism management: Examples from the hotel industry. Tourism Management, 32, 207-214. http://doi.org/10.1016/j.tourman.2010.05.020

Tussyadiah, I. P., \& Zach, F. (2017). Identifying salient attributes of peer-to-peer accommodation experience. Journal of Travel and Tourism Marketing, 34, 636-652. http://doi.org/10.1080/10548408.2016.1209153

Uchiyama, K. (2009). A Concise Theoretical Grounding of Action Research : Based on Checkland's Soft Systems Methodolog and Kimura's Phenomenological Psychiatry. General Systems.

Vargo, S. L., Koskela-Huotari, K., Baron, S., Edvardsson, B., Reynoso, J., \& Colurcio, M. (2017). A systems perspective on markets - Toward a research agenda. Journal of Business Research, 79, 260-268. http://doi.org/10.1016/j.jbusres.2017.03.011 
Vargo, S. L., \& Lusch, R. F. (2004). Evolving to a New Dominant Logic for Marketing. Journal of Marketing, 68, 1-17. http://doi.org/10.1509/jmkg.68.1.1.24036

Vargo, S. L., \& Lusch, R. F. (2008). Service-dominant logic: Continuing the evolution. Journal of the Academy of Marketing Science, 36(1), 1-10. http://doi.org/10.1007/s11747-007-0069-6

Vargo, S. L., \& Lusch, R. F. (2014). Inversions of service-dominant logic. Marketing Theory, 14, 239-248. http://doi.org/10.1177/1470593114534339

Vargo, S. L., \& Lusch, R. F. (2016). Institutions and axioms: an extension and update of service-dominant logic. Journal of the Academy of Marketing Science, 44, 5-23. http://doi.org/10.1007/s11747-015-0456-3

Vargo, S. L., \& Lusch, R. F. (2017). Service-dominant logic 2025. International Journal of Research in Marketing, 34, 46-67. http://doi.org/10.1016/j.ijresmar.2016.11.001

Vargo, S. L., Wieland, H., \& Akaka, M. A. (2015). Innovation through institutionalization: A service ecosystems perspective. Industrial Marketing Management, 44, 63-72. http://doi.org/10.1016/j.indmarman.2014.10.008

Walker, D. H. T., \& Steinfort, P. (2013). Using an improved rich pictures approach to improve project situational analysis in complex aid reconstruction development projects. International Journal of Disaster Resilience in the Built Environment, 4, 182-198. http://doi.org/10.1108/IJDRBE-12-2011$\underline{0043}$

Zervas, G., Proserpio, D., \& Byers, J. W. (2017). The Rise of the Sharing Economy: Estimating the Impact of Airbnb on the Hotel Industry. Journal of Marketing Research, LIV, jmr.15.0204. http://doi.org/10.1509/jmr.15.0204 